\title{
Mainstream theories of corporate governance and the corporate governance - firm performance relationship
}

\section{Nguyen Van Tuan*}

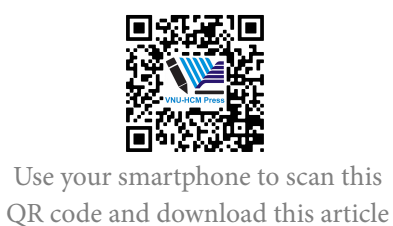

Faculty of Economics and Business Administration, Dalat University, Vietnam

\section{Correspondence}

Nguyen Van Tuan, Faculty of Economics and Business Administration, Dalat University, Vietnam

Email: tuannv@dlu.edu.vn

History

- Received: 14-03-2021

- Accepted: 26-05-2021

- Published: 09-06-2021

DOI : 10.32508/stdjelm.v5i3.781

\section{Check for updates}

\section{Copyright}

(c) VNU-HCM Press. This is an openaccess article distributed under the terms of the Creative Commons Attribution 4.0 International license.

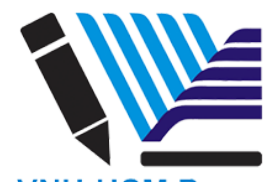

VNU-HCM Press

\begin{abstract}
This paper reviews the mainstream theories of corporate governance and the relationship between corporate governance structures and firm financial performance. We show that the four predominant theories often employed to study the corporate governance - firm performance relationship are agency theory, stewardship theory, resource dependence theory, and institutional theory. In spite of being an overwhelmingly predominant theoretical approach in corporate governance studies, agency theory has recently been criticized for not fully reflect corporate governance practices in various institutional contexts. It is, therefore, necessary to re-examine the traditional agency framework to understand the corporate governance - firm performance relationship in various institutional environments. There are also calls for the application of a multi-theoretical approach to capture the complex nature of the corporate governance - firm performance relationship. It is also clear from our review that the effect of corporate governance on firm performance is inconclusive as empirical findings concerning this relationship are mixed in different analysis contexts. It is argued that such inconclusive findings of the corporate governance - firm performance relationship may be caused by the national institution differences and the imperfection of estimation techniques. Several recent studies in corporate governance support the view that the implementation of corporate governance mechanisms in a country is influenced by its institutional environment. For this reason, the effectiveness of corporate governance mechanisms also varies from country to country, or in other words, it is country-specific. This suggests that future research focusing on cross-national comparative contexts may provide more insight or in-depth information on the corporate governance - firm performance relationship. We also suggest that the potential mediating impacts of institutional characteristics on the corporate governance - firm performance relationship should be taken into consideration when conducting cross-country comparative corporate governance studies.
\end{abstract}

Key words: Agency theory, Corporate governance, Institutional theory, Resource dependence theory, Stewardship theory

\section{INTRODUCTION}

It is indicated that there are three primary sources of inspiration for most of the empirical studies in the field of corporate governance, including agency theory, stewardship theory, and resource dependence theory ${ }^{1}$. Among them, the agency theory is regarded as the overwhelmingly predominant theoretical approach in corporate governance studies ${ }^{2-5}$. However, scholars increasingly realize that the agency theory depicts only a part of the complicated picture of an organization ${ }^{6}$, and insufficiently presents corporate governance practices in all analysis contexts due to cross-national differences of the institution ${ }^{7}$. This leads to the need for the application of institutional theory to conduct cross-national comparative analyses of corporate governance

Consequently, there are recent calls for the application of a multi-theoretical approach to capture the com- plex nature of the corporate governance - firm performance (CGFP) relationship ${ }^{2,4,7-12}$. It is suggested that the agency theory should be complemented by stewardship theory ${ }^{10}$, by resource dependence theory $^{9,10}$. It is also suggested that the choice of what theory to lay the foundation of the debate about corporate governance depends on our various study aspects, which can be generalized to four major groups, including (i) Economics and management; (ii) Culture and sociology; (iii) Law; and (iv) Politics ${ }^{8}$.

From the point of view of economics and management, in which corporate finance is one of the vital components, a large number of prior studies adopted agency theory as the major theoretic framework to investigate the CGFP relationship in diverse contexts of analysis $^{13}$. More specifically, Letza, Sun, and Kirkbride $^{3}$ conclude that the finance view and agency theory are employed as the predominant approach of studies on corporate governance in the past decades. 
This paper aims to review the mainstream theories of corporate governance and the relationship between corporate governance structures and firm financial performance. The paper proceeds with an overview of agency theory, stewardship theory, resource dependence theory, and institutional theory. The theoretical frameworks and typically empirical findings of the CGFP relationship will then be reviewed in the second subsection.

\section{FOUR PREDOMINANT THEORIES IN CORPORATE GOVERNANCE RESEARCH}

\section{Agency theory}

An agency relationship is defined as "a contract under which one or more persons (the principal(s)) engage another person (the agent) to perform some service on their behalf which involves delegating some decision-making authority to the agent" ${ }^{14}$. This implies that the separation between control functions (of agents) and ownership (of principals) in contemporary public corporations is a potential source of interest conflict between agents and principals, called the principal-agent problem. According to Eisenhardt ${ }^{6}$, the principal-agent relationship arises from three primary assumptions about people (both the owners and the managers are opportunistic, rational, and riskantipathetic individuals), organizations (aim distinction among members and information asymmetry between the owners and the managers), and information (information is regarded as a purchasable commodity). Correspondingly, it is assumed that (i) both owners and managers are opportunistic, rational, and risk-antipathetic individuals; (ii) the goals of members in an organization are dissimilar and information asymmetry exists between owners and managers; and (iii) information is regarded as a purchasable commodity.

Agency theory, therefore, is generally concerned with aligning the interest conflictions between principals and agents. Jensen and Meckling ${ }^{14}$ and Shleifer and Vishny ${ }^{5}$ among others argue that inherently opportunistic managers tend to abuse a firm's resources to pursue their own egocentric benefits rather than those of the owners. Agency theory suggests that firms should establish appropriate governance structures to monitor the behaviors of managers and prevent owners from such abuses, i.e. mitigate the principalagent problem ${ }^{14}$. Jensen and Meckling ${ }^{14}$ also suggest that establishing these governance structures generates three different types of cost which shareholders have to bear: (i) Monitoring costs (expenditures by the principal to control the agent's actions); (ii) Bonding costs (expenditures by the agent to make up to the principal for the agent's harmful activities); and (iii) Residual loss (the decrease in the principal's welfare caused by the separation between the agent's decisions $)^{14}$. However, the impacts of those costs can be minimized and firm financial performance may be enhanced provided that firms can establish effective governance mechanisms ${ }^{5}$. It is also necessary to distinguish between the terms of 'system' and 'mechanism' in the corporate governance literature. While the corporate governance system focuses on corporate governance at the country level, the term of corporate governance mechanisms refers to corporate governance at the firm level. More specifically, a corporate governance system deals with the legal framework, institutional and cultural factors of a country "shaping the patterns of influence that stakeholders exert on managerial decision-making" ${ }^{15}$. Whereas, the term of corporate governance mechanisms may be understood as the ways used to solve corporate governance problems at the firm level ${ }^{16}$. However, it should be noted that the term 'system' is sometimes used with the same meaning as 'mechanisms' ${ }^{17}$ or 'structures' ${ }^{7}$. Many prior studies interchangeably use the term 'mechanisms' and/or 'structures' to deals with corporate governance at the level of firm.

The extant corporate governance literature ${ }^{16,18-22}$ suggests some such mechanisms to align the interest conflicts between the owners and the managers, including internal mechanisms (such as board size, board diversity, board committees, board independence, managerial ownership, and leverage, among others), and external mechanisms (such as blockholder ownership, institutional ownership, the market for corporate control and managerial control, and legal framework). Although the above-mentioned dual classification of corporate governance mechanisms is widely accepted, it should be noted that the denotation of each category is various between schol$\operatorname{ars}^{16}$ and, in fact, most researches primarily focus on the impact of each mechanism of corporate governance on financial performance ${ }^{13,21}$. For example, in many corporate governance studies, board size, board diversity, board committees, and board independence (including board composition and board leadership structure) are regarded as determinants of the board attributes. It should also be noticed that there is no consensus among researchers about the connotation of the terminology "board attributes". For example, Zahra and Pearce ${ }^{23}$ state that there are four board attributes including (i) Composition; (ii) Characteristics; (iii) Structure; and (iv) Process. 
They demonstrate that board composition refers to the size of board and the combination of various types of directors (such as executive or non-executive directors). Board characteristics mention the experience, independence, industry background of directors. Board structure refers to the organization and allocation of personnel to board committees. Board process mentions the decision-making associated with the board's activities and styles. In line with previous research ${ }^{24-26}$, many studies consistently use the terms of board attributes or board structure to refer to the combination of size, committees, diversity, meetings, independence, and leadership structure of the board. Meanwhile, managerial ownership and block-holder ownership are two major features of the ownership structure. The choice of mechanisms to study will be based on the availability of data in each country under the current research.

\section{Resource dependence theory}

Resource dependence theorists take the view that a firm is an open social entity which is closely connected with the conditions of its environment, such as human resource, capital resource, and informa$\operatorname{tion}^{27,28}$. In this regard, resource dependence theory suggests that the board of directors plays a crucial role in linking the firm and those social resources ${ }^{27,28}$. More specifically, the function of the board is to not only monitor managerial behaviors (as mentioned by agency theory) but also provide essential resources that are needed to enhance firm performance and/or ensure those resources via connections with the external environment ${ }^{29}$. Pfeffer and Salancik ${ }^{27}$ assert that the board's provision of essential resources includes: "(i) advice and counsel; (ii) legitimacy; (iii) channels for communicating information between external organizations and the firm; and (iv) preferential access to commitments or support from important elements outside the firm" ${ }^{9}$.

In other words, apart from the monitoring function, the board also serves as a resource provider. Hillman and Dalziel ${ }^{9}$ refer to the ability of the board to bring essential resources to the firm as "board capital" including "human capital (experience, expertise, reputation) and relational capital (network of ties to other firms and external contingencies). They also state that the question examined by resource dependence theory is how such board capital can lead to a board's provision of resources and subsequent firm performance. In summary, resource dependence theory offers two important implications regarding the board: (i) environmental pressures and demands may have impacts on board composition, and (ii) differences in board composition may result in various firm performance $^{28}$.

For the region of East Asia, although there is preliminary evidence to state that resource dependence theory can better explain the board's functions of East Asian companies than agency theory ${ }^{30}$, it is suggested that the combining of the two theoretical approaches will provide a sound grasp of the board's functions ${ }^{9}$.

\section{Institutional theory}

Young, et al. ${ }^{30}$, based on studies of Orru, Biggart, and Hamilton (1997) and Peng (2000), state that the main reason for distinctions between board's functions of East Asian firms and those of Western firms is the differences of the institutional and regulatory environments between the two regions. This leads to the need for the application of institutional theory to conduct cross-national comparative analyses of corporate governance. Indeed, Aguilera and Jackson ${ }^{8}$ strongly argue that "comparative approaches to studying corporate governance must, by nature, deal with the diversity across countries and over time" (p. 491). So what is the role of institutional theory in comparative studies of corporate governance? and how can national institutions affect their corporate governance mechanisms? The theory of institution is drawn from various domains of social science, such as economic, sociology, and political science ${ }^{\mathrm{a} 8}$. From the perspective of economics and political science, 'institution' is defined as "the humanly devised constraints that structure political, economic and social interaction. They consist of both informal constraints (sanctions, taboos, customs, traditions, and codes of conduct), and formal rules (constitutions, laws, property rights)" 31 . In short, institutions may be seen as rules and constraints designed to direct and justify the interactive behaviors of individuals and organizations.

Concerning the role of institutional theory in studying corporate governance, several recent studies $^{11,24,30-35}$ support the general view that the implementation of corporate governance mechanisms in a country is influenced by its institutional environment. For this reason, the effectiveness of corporate governance mechanisms also varies from country to country. It is suggested that the factors of the national institutional environment such as culture, financial system, corporate ownership patterns, legal tradition, and economic situation ${ }^{36,37}$

${ }^{a}$ Which are categorized as two major branches by Ahrens, et al. (31), including (i) Political science and economics oriented institutional theory; and (ii) Sociology and organization oriented institutional theory. 
are important determinants in analyzing different models of organization and their different levels of performance ${ }^{38}$, as well as in creating diverse national corporate governance practices ${ }^{37}$.

For instance, in terms of legal tradition, La Porta, Lopez-de-Silanes, Shleifer, and Vishny ${ }^{39}$, by investigating the nexus between legal tradition and corporate governance for a sample of 49 countries, show that the investor protection and the capital market development of civil law countries are weaker than those of common law countries, and as a result, the corporate governance codes of common law countries concentrate on protecting the shareholders' rights. Similarly, Love ${ }^{13}$ reviews previous research and realizes that whereas most extant studies are conducted on particular nations, some cross-national comparative analyses examine the CGFP relationship (firm-level) within the interaction with corporate governance system (country level). According to those several comparative studies, it is suggested that corporate governance at the firm level has more influence on firm valuation in countries with weaker legal protection ${ }^{13}$. Moreover, in countries with incomplete legal systems and weak legal enforcement, corporate governance mechanisms may be adopted for legitimate targets rather than for firm performance ${ }^{2}$. Consequently, the nominal commitment of good corporate governance practice at the firm level is not necessarily to be the real implementation, and as such, cannot relate to firm performance. In that case, the corporate governance practice is a purely normal matter rather than fact ${ }^{13,40}$.

The above examples illustrate the impacts of the national institutional factors on corporate governance practices at the firm level as well as their importance to cross-country comparisons of corporate governance and firm performance. Based on a study of Aguilera and Jackson ${ }^{34}$, Ahrens, et al. ${ }^{32}$ strongly argue that "agency problems may vary across different national settings and implies that researchers should integrate the agency framework with institutional analysis to generate robust predictions. Future research should expand on this concept and seek to more explicitly examine the nature of agency conflicts and their implications in different institutional settings" (p. 323). For this reason, cross-country comparisons of corporate governance and firm performance, despite at firm level or country level, must take into account the abovementioned institutional factors. In general, although there is a growing consensus on the role of a national institution in corporate governance practices, crossnational comparative research on the CGFP relationship is still in the early stage of development ${ }^{34}$. Examining what institutional factors matter and how they affect corporate governance practices, therefore, is considered as the primary objective of comparative studies of corporate governance ${ }^{12,32,34,41,42}$.

Several recent studies have focused on the CGFP relationship in emerging markets, where legal environments, corporate governance systems, and institutional frameworks are considerably different from those of developed markets ${ }^{22,43-47}$. These studies indirectly show that empirical evidence obtained from various legal and institutional environments will not only significantly contribute to the extant literature of the CGFP relationship ${ }^{48}$, but also indicate that the unquestioning application of overseas corporate governance mechanisms but not take the distinctions of institution characteristics into consideration is not always the best choice 22 .

\section{Stewardship theory}

Whereas agency theorists view managers as opportunists, the proponents of the stewardship theory believe that they are naturally reliable individuals and tend to do good jobs to become good stewards of the company's resources, as well as to maximize the company's profit ${ }^{49}$. This means that, under stewardship theory, the managerial motivation is seeking to maximize the performance of an organization rather than pursuing individual self-interest as mentioned by agency theory. If that is the case, there is no reason to believe that the conflict of interest between the owners and the managers, as indicated by agency theory, is real.

As a result, stewardship theorists advise that managers should be fully empowered to effectively operate their organization by, for example, combining, rather than separating, the role of board chairman and chief executive officer (the CEO) in the sole position, known as the CEO duality ${ }^{3,49}$.

\section{THE CORPORATE GOVERNANCE-FIRM PERFORMANCE RELATIONSHIP}

The significantly positive relationship between corporate governance mechanisms and financial performance in large economies, especially in the US and the UK, is supported by most extant studies ${ }^{21}$. It is also argued that this relationship is stronger with market-based measures of performance and weaker with accounting-based measures ${ }^{13}$. However, the empirical findings concerning this link are mixed and inconclusive in different analysis contexts ${ }^{22}$. In a noticeable work, Ahrens, et al. ${ }^{32}$ emphasize that "despite enormous volume of research, we still know very little 
about corporate governance. We cannot say, for example, that specific ownership or board structures lead to better economic performance" (p. 312). It is argued that such vague findings of the CGFP relationship may be caused by: (i) The institutional differences between countries ${ }^{30,32-34}$; and (ii) The imperfection of measurement methods ${ }^{13,19,32}$.

\section{The nexus between board attributes and fi- nancial performance}

The board of directors is one of the vital determinants of the internal corporate governance mechanisms ${ }^{50}$ and its relationship to financial performance has attracted many scholars for a long time ${ }^{2}$. Although such a relationship is explained and forecasted by several theories such as agency theory or resource dependence theory ${ }^{9}$, empirical findings of the influence of the board on firm performance are inconclusive ${ }^{4,19}$. The extant literature of corporate governance shows that the attributes of the board may include board size, board diversity, board committees, and board independence (including board composition and board leadership structure), among others. The next subsections will review the link between these board attributes with firm financial performance in the extant literature.

\section{Board size and firm financial performance}

Among various board characteristics, the size of the board of directors is believed to be one of the most essential characteristics ${ }^{24,51}$. Whereas the relationship between board size and firm performance is supported by agency, stewardship, and resource dependence theories, there is not a consensus among scholars about the direction of such a nexus in practice ${ }^{51}$. Indeed, based on agency theory, M. Jensen ${ }^{52}$ argues that firm performance will be able to be enhanced if the size of board is small and suggests that the optimal threshold of board size should not be over eight members. The perspective of keeping a small board size to function well is also achieved consensus by Lipton and Lorsch ${ }^{53}$; Sonnenfeld ${ }^{54}$; and Yermack ${ }^{55}$, among others. From the stewardship theory's perspective, Muth and Donaldson ${ }^{26}$ provide a similar prediction that small boards positively impact firm performance. They argued that small boards react better to firm demands because they help directors to join in decisionmaking through effective interpersonal communication, as well as help in enhancing social cohesion. Based on resource dependence theory, Dalton, Daily, Johnson, and Ellstrand ${ }^{51}$ recommend the opposite opinion that the larger size of board is, the better firm financial performance will be. Likewise, Firstenberg and Malkiel take the view that a small board of directors cannot offer a set of members with diverse managerial experience, gender, nationality, and as such, it may restrict its capabilities in terms of stimulating various perspectives.

Empirically, the link between board size and firm financial performance in the extant literature is inconclusive as well. Yermack ${ }^{55}$ finds an inverse relationship between board size and market-based measurement of corporate governance (firm value) in a sample of 452 large United States industrial companies for the period of 1984-1991. His finding is consistent with the agency theory that small boards tend to perform more effectively than large ones. This view is supported by several recent studies of the CGFP relationship ${ }^{56,57}$. By contrast, Beiner, Drobetz, Schmid, and Zimmermann ${ }^{58}$ use the data of firms quoted at the Swiss Exchange by the end of 2002 and develop a comprehensive system of seven simultaneous equations. Their study aims at examining the relationship between selected corporate governance mechanisms and firm valuation through applying the threestage least squares method. Their research reveals that board size is positively related to firm value.

Besides, there is also empirical evidence that shows no statistically significant relationship between board size and financial performance. For example, Reddy, et al. ${ }^{21}$, using panel data for the NZX top 50 publiclylisted companies over the period 1999-2007 in New Zealand, discover that there is no statistical evidence to believe such a nexus is significant. Similarly, a study by Aljifri and Moustafa ${ }^{16}$, employing a sample of 51 firms listed in Dubai Financial Market and the Abu Dubai Securities Market, shows that board size has an insignificant impact on firm performance.

Meanwhile, another study by Mak and Kusnadi ${ }^{57}$, employing data from listed firms in Malaysia and Singapore, reveals that the relationships between board size and firm value (measured by Tobin's $Q$ ) in both countries are inverse. It is to be regretted that the study of Mak and Kusnadi does purely use multinational data to examine the role of board size to firm performance, but not use a comparative approach to clarify the nature of the board size-firm performance relationship in different national contexts.

\section{Board committees and firm financial perfor- mance}

Agency theory considers the monitoring of behaviors of managers (agents) to protect the interests of owners (principals) as the primary function of the board ${ }^{6,14}$. 
Thus, it is assumed that the more independent the board is from management, the better it will exercise its monitoring function. Seen from this point of view, Maassen ${ }^{59}$ asserts that one of the strategies to mitigate the influence of management on board independence is the establishment of board committees and formal division of board roles in the organizational structure of the board. Independent boards, in turn, may have a positive impact on firm performance ${ }^{26}$.

Conversely, stewardship theory advocates that there is no conflict of interests between management, directors, and shareholders ${ }^{49}$, and therefore, the formation of board committees becomes unnecessary ${ }^{59}$. Instead, stewardship theory suggests that the board may become an important strategic means to maximize the benefits of shareholders once its power structure is united and is constituted by experienced members ${ }^{3,49,59}$. Seen from this point of view, it is argued that the separation of board authority structure may cause the trouble of information asymmetries and unnecessary bureaucratic structures that may hinder the strategic decision-making processes of firms (Maassen, 2002), and as a result, may have a negative impact on firm performance.

\section{Board independence and firm financial per- formance}

According to Muth and Donaldson ${ }^{26}$, the level of board independence is usually measured by two structural variables, including (i) Board composition and (ii) Board leadership structure. While board composition is often defined as the proportion of outside directors on the board, board leadership structure mentions whether a company has one position combining the duties of the CEO with those of the board chairman (known as the CEO duality or unitary leadership), or whether it allocates these positions to different members (known as the CEO nonduality or dual leadership) ${ }^{10,20,25,26,41,60,61}$. The direction of the influence of board independence on firm performance can be predicted by three predominant theories in corporate governance literature, including agency, stewardship, resource dependence, and institutional theories.

Agency theory suggests that the higher level of nonexecutive directors on the board is, the better the monitoring function of the board will be $\mathrm{b}^{10,14,50}$. It is assumed that non-executive directors may exercise their monitoring function better than executive directors as they are less dependent on management and more interested in protecting their renown in the external labor market ${ }^{50}$. Nicholson and Kiel (2007) discuss that if the monitoring function of the board is implemented effectively thanks to board independence, the chance for managers to gain self-interest at the expense of shareholders will be minimized, and as a result, shareholders will obtain larger benefit.

Proponents of agency theory also argue that CEO duality hinders the board from implementing its monitoring function because when the CEO is also the board chairman, "the impartiality of the board is compromised" 49 , and the power of monitoring can be abused for self-interests of the CEO. In other words, it is obvious that non-executive dominated board and CEO non-duality, seen from the agency theory's perspective, are regarded as characteristics of an independent board which, in turn, result in better monitoring of self-interested behavior of managers ${ }^{4}$. It is reasonable to assume that both non-executive dominated board and CEO non-duality will lead to the diffusion and allocation of management decisions and monitoring decisions that help diminish agency problems ${ }^{50}$.

Conversely, stewardship theory suggests that executive directors can take advantage of information and knowledge about the corporation to make better decisions than those of non-executive directors ${ }^{49}$. More specifically, Muth and Donaldson ${ }^{26}$ state that " $a$ majority of executive directors provides the depth of experience, technical expertise, and ease of communication needed for effective board functioning" (p. 9). Being naturally trustworthy individuals and good stewards of the company's resources, executive directors tend to do good jobs, and as such, their decisions naturally aim at maximizing shareholders' benefit ${ }^{10}$.

Hence, the stewardship theory forecasts that the higher proportion of executive directors will lead to high-quality decision-making and, as a result, have positive effects on firm performance ${ }^{10}$. tewardship theory also advises that managers should be fully empowered to effectively operate their organization by combining, rather than separating, the role of board chairman and the $\mathrm{CEO}^{3,49}$. CEO duality is assumed to offer a good grasp of the company's operating environment ${ }^{62}$ and a unification of direction and strong command and control ${ }^{47}$ that will beneficially affect firm performance.

Resources dependence theorists are in favor of the stewardship theory's perspective on board composition. Daily, et al. ${ }^{4}$ argue that non-executive directors provide an approach to vital resources of companies. To illustrate this point of view, they say that nonexecutive directors, "who are also executives of financial institutions, may assist in securing favorable lines of credit" (p.372); or non-executive directors, "who are partners in a law firm, provide legal advice, either in board meetings or in private communication with firm 
executives, that may otherwise be more costly for the firm to secure" (p. 372). If that is the case, it is reasonable to infer that the higher presence of non-executive directors on the board will have a positive impact on firm performance.

The nexus between ownership structures and financial performance

Block-holder ownership and firm financial performance

From agency theory's perspective, the concentration of ownership is considered as one of the important mechanisms to monitor managerial behaviors. The concentrated ownership by shareholders (such as institutional and individual investors, and blockholders) helps in reducing agency problems arising from the separation of ownership and control ${ }^{5}$. It is argued that the larger company stocks the blockholders own, the stronger power they will gain to make management serve their benefits ${ }^{63}$. Furthermore, holding a large proportion of company assets, institutional investors or block-holders have greater intensive to be involved in managerial behaviors to ensure that company's interests and their benefits are not expropriated, that, in turn, result in better firm financial performance ${ }^{22}$. However, while block-holder ownership is regarded as a mechanism to reduce the conflicts between shareholders and management, it may be a potential source of conflicts of interest between minority shareholders and majority ones ${ }^{64}$.

\section{Managerial ownership and firm financial performance}

Managerial ownership is usually defined as the stock ownership of a company inside managers (including executive directors, non-executive directors, and other senior managers). The relationship of managerial ownership and firm performance is predicted by two theoretical hypotheses in the current literature, consisting of the convergence-of-interests hypothesis and entrenchment hypothesis. The convergence-ofinterests hypothesis, based on the agency theory's perspective, suggests that increasing managerial ownership will result in diminishing the conflicts of interests between outside shareholders and inside managers ${ }^{14}$. The reason is when the managers owned a larger proportion of shares, their benefits will be more closely related to the other shareholders' benefits. Therefore, maximizing the shareholders' benefits, in this case, is synonymous with maximizing their wealth ${ }^{25}$. It is logical to infer that the harmonization of interests between inside managers and outside shareholders will be able to be achieved if the managers have further company stocks ${ }^{48}$. In other words, the larger the managerial ownership is, the more active the incentive for the managers to monitor their managerial behaviors will be that may mitigate agency costs and improve firm performance ${ }^{21,65}$.

In contrast, the entrenchment hypothesis proposes that when inside managers own a low level of company stocks, they, under the competitive pressures of market forces, may have a higher incentive to make suitable decisions for the benefits of the other outside shareholders ${ }^{66}$. However, it is also argued that when inside managers own a higher level of company stocks and have higher voting power to protect themselves from such pressures, they may pursue self-interests without effective monitoring ${ }^{65}$.

\section{CONCLUSIONS}

Based on the literature review, this paper summarizes four predominant theories often employed to study the CGFP relationship, namely agency theory, stewardship theory, resource dependence theory, and institutional theory. While most extant corporate governance studies base their arguments on the agency theory, scholars increasingly realize that the agency theory depicts only a part of the complicated nature of the CGFP relationship. Thus, there are recent calls for the application of a multi-theoretical approach to capture this complex nature. Second, although there is a growing consensus on the role of a national institution in corporate governance practices, crossnational comparative research on the CGFP relationship is still in the early stage of development. Third, empirical findings regarding the CGFP relationship are mixed and inconclusive. We conclude that most extant corporate governance studies focus on an individual country so they are unable to offer insights into the nature of the CGFP relationship in different analysis contexts.

\section{LIST OF ABBREVIATIONS}

CGFP relationship: The corporate governance-firm performance relationship

CEO: Chief executive officer

US: The United States of America

UK: The United Kingdom

NZX: New Zealand's Exchange

\section{COMPETING INTERESTS}

The author declares that they have no conflicts of interest 


\section{AUTHOR CONTRIBUTION}

The author confirms sole responsibility for the manuscript preparation

\section{REFERENCES}

1. CLSA. Corporate governance watch 2010. Gill A, Allen J, Powell S, editors. Hong Kong: Credit Lyonnais Securities Asia; 2010;.

2. Lynall MD, Golden BR, Hillman AJ. Board composition from adolescence to maturity: A multitheoretic view. Academy of Management Review. 2003;28(3):416-31;Available from: https://doi.org/10.5465/amr.2003.10196743.

3. Letza S, Sun X, Kirkbride J. Shareholding versus stakeholding: A critical review of corporate governance. Corporate Governance: An International Review. 2004;12(3):242-62;Available from: https://doi.org/10.1111/j.1467-8683.2004.00367.x.

4. Daily CM, Dalton DR, Cannella AA. Corporate governance: Decades of dialogue and data. Academy of Management Review. 2003;28(3):371-82;Available from: https://doi.org/10. 5465/amr.2003.10196703.

5. Shleifer A, Vishny RW. A survey of corporate governance. The Journal of Finance. 1997;52(2):737-83;Available from: https:// doi.org/10.1111/j.1540-6261.1997.tb04820.x.

6. Eisenhardt KM. Agency theory: An assessment and review. Academy of Management Review. 1989;14(1):57-74;Available from: https://doi.org/10.5465/amr.1989.4279003.

7. Young MN, Peng MW, Ahlstrom D, Bruton GD, Jiang Y. Corporate governance in emerging economies: A review of the principal-principal perspective. Journal of Management Studies. 2008;45(1):196-220;Available from: https://doi.org/ 10.1111/j.1467-6486.2007.00752.x.

8. Aguilera RV, Jackson G. Comparative and international corporate governance. Academy of Management Annals. 2010;4(1):485-556;Available from: https://doi.org/10.5465/19416520.2010.495525.

9. Hillman AJ, Dalziel T. Boards of directors and firm performance: Integrating agency and resource dependence perspectives. Academy of Management Review. 2003;28(3):38396;Available from: https://doi.org/10.5465/amr.2003.10196729.

10. Nicholson GJ, Kiel GC. Can directors impact performance? A case-based test of three theories of corporate governance. Corporate Governance: An International Review. 2007;15(4):585-608;Available from: https://doi.org/10.1111/j. 1467-8683.2007.00590.x.

11. Peng MW. Outside directors and firm performance during institutional transitions. Strategic Management Journal. 2004;25(5):453-71;Available from: https://doi.org/10.1002/ smj.390.

12. Nguyen $T$, Nguyen A, Nguyen $M$, Truong $T$. Is national governance quality a key moderator of the boardroom gender diversity-firm performance relationship? International evidence from a multi-hierarchical analysis. International Review of Economics \& Finance. 2021;73(C):370-90;Available from: https://doi.org/10.1016/j.iref.2021.01.013.

13. Love I. Corporate governance and performance around the world: What we know and what we don't. The World Bank Research Observer. 2011;26(1):42-70;Available from: https://doi. org/10.1093/wbro/lkp030.

14. Jensen M, Meckling W. Theory of the firm: Managerial behaviour, agency cost, and ownership structure. Journal of Financial Economics. 1976;3(5):305-60;Available from: https:// doi.org/10.1016/0304-405X(76)90026-X.

15. Weimer J, Pape J. A taxonomy of systems of corporate governance. Corporate Governance: An International Review. 1999;7(2):152-66;Available from: https://doi.org/10.1111/1467-8683.00143.

16. Aljifri $K$, Moustafa $M$. The impact of corporate governance mechanisms on the performance of UAE firms: An empirical analysis. Journal of Economic \& Administrative Sciences. 2007;23(2):71-93;Available from: https://doi.org/10. $1108 / 10264116200700008$.
17. Denis DK, McConnell JJ. International corporate governance. Journal of Financial and Quantitative Analysis. 2003;38(1):136;Available from: https://doi.org/10.2307/4126762.

18. Ang JS, Ding DK. Government ownership and the performance of government-linked companies: The case of Singapore. Journal of Multinational Financial Management. 2006;16(1):64-88;Available from: https://doi.org/10.1016/j.mulfin.2005.04.010.

19. Bhagat S, Bolton B. Corporate governance and firm performance. Journal of Corporate Finance. 2008;14(3):25773;Available from: https://doi.org/10.1016/j.jcorpfin.2008.03. 006.

20. Elsayed K. Board size and corporate performance: The missing role of board leadership structure. Journal of Management and Governance. 2011;15(3):415-46;Available from: https:// doi.org/10.1007/s10997-009-9110-0.

21. Reddy K, Locke S, Scrimgeour F. The efficacy of principlebased corporate governance practices and firm financial performance: An empirical investigation. International Journal of Managerial Finance. 2010;6(3):190-219;Available from: https: //doi.org/10.1108/17439131011056224.

22. Haniffa R, Hudaib M. Corporate governance structure and performance of Malaysian listed companies. Journal of Business Finance and Accounting. 2006;33(7\&8):1034-62;Available from: https://doi.org/10.1111/j.1468-5957.2006.00594.x.

23. Zahra SA, Pearce JA. Boards of directors and corporate financial performance: A review and integrative model. Journal of Management. 1989;15(2):291-334;Available from: https://doi. org/10.1177/014920638901500208.

24. Bonn I, Yoshikawa T, Phan PH. Effects of board structure on firm performance: A comparison between Japan and Australia. Asian Business \& Management. 2004;3(1):10525;Available from: https://doi.org/10.1057/palgrave.abm. 9200068.

25. Mak YT, Li Y. Determinants of corporate ownership and board structure: Evidence from Singapore. Journal of Corporate Finance. 2001;7(3):235-56;Available from: https://doi.org/10. 1016/S0929-1199(01)00021-9.

26. Muth M, Donaldson L. Stewardship theory and board structure: A contingency approach. Corporate Governance: An International Review. 1998;6(1):5-28;Available from: https://doi. org/10.1111/1467-8683.00076.

27. Pfeffer J. Size, composition, and function of hospital boards of directors: A study of organization-environment linkage. Administrative Science Quarterly. 1973;18(3):349-64;Available from: https://doi.org/10.2307/2391668.

28. Boyd B. Corporate linkages and organizational environment: A test of the resource dependence model. Strategic Management Journal. 1990;11(6):419-30;Available from: https://doi. org/10.1002/smj.4250110602.

29. Hillman AJ, Cannella AA, Paetzold RL. The resource dependence role of corporate directors: Strategic adaptation of board composition in response to environmental change. Journal of Management Studies. 2000;37(2):235-56;Available from: https://doi.org/10.1111/1467-6486.00179.

30. Young MN, Ahlstrom D, Bruton GD, Chan ES. The resource dependence, service, and control functions of boards of directors in Hong Kong and Taiwanese firms. Asia Pacific Journal of Management. 2001;18(2):223-44;Available from: https: //doi.org/10.1023/A:1010624109010.

31. North DC. Institutions. Journal of Economic Perspectives. 1991;5(1):97-112;Available from: https://doi.org/10.1257/jep.5. 1.97.

32. Ahrens $\mathrm{T}$, Filatotchev I, Thomsen $\mathrm{S}$. The research frontier in corporate governance. Journal of Management and Governance. 2011;15(3):311-25;Available from: https://doi.org/10. 1007/s10997-009-9115-8.

33. Aguilera RV, Filatotchev I, Gospel H, Jackson G. An organizational approach to comparative corporate governance: Costs, contingencies, and complementarities. Organization Science. 2008;19(3):475-92;Available from: https://doi.org/10. 
1287/orsc. 1070.0322

34. Aguilera RV, Jackson G. The cross-national diversity of corporate governance: Dimensions and determinants. Academy of Management Review. 2003;28(3):447-65;Available from: https://doi.org/10.5465/amr.2003.10196772.

35. Luoma P, Goodstein J. Stakeholders, and corporate boards: Institutional influences on board composition and structure. Academy of Management journal. 1999;42(5):55363;Available from: https://doi.org/10.2307/256976.

36. Zattoni A, Cuomo F. Why adopt codes of good governance? A comparison of institutional and efficiency perspectives. Corporate Governance: An International Review. 2008;16(1):115;Available from: https://doi.org/10.1111/j.1467-8683.2008. 00661.x.

37. Davies $M$, Schlitzer B. The impracticality of an international "one size fits all" corporate governance code of best practice. Managerial Auditing Journal. 2008;23(6):532-44;Available from: https://doi.org/10.1108/02686900810882093.

38. Millar CCJM, Eldomiaty TI, Choi CJ, Hilton B. Corporate governance and institutional transparency in emerging markets. Journal of Business Ethics. 2005;59(1):163-74;Available from: https://doi.org/10.1007/s10551-005-3412-1.

39. La Porta R, Lopez-de-Silanes F, Shleifer A, Vishny R. Legal determinants of external finance. The Journal of Finance. 1997;52(3):1131-50;Available from: https://doi.org/10.1111/j. 1540-6261.1997.tb02727.x.

40. Chuanrommanee W, Swierczek FW. Corporate governance in ASEAN financial corporations: Reality or illusion? Corporate Governance: An International Review. 2007;15(2):27283;Available from: https://doi.org/10.1111/j.1467-8683.2007. 00559.x.

41. Nguyen T. Do female directors add value? Acta Universitatis Danubius CEconomica. 2017;13(3):169-77;

42. Nguyen $\mathrm{T}$, Nguyen $\mathrm{T}$. Corporate governance structures and performance of firms in Asian market: A comparative analysis between Singapore and Vietnam. Organizations and Markets in Emerging Economies. 2016;7(2):112-40;Available from: https://doi.org/10.15388/omee.2016.7.2.14210.

43. Cheung SYL, Chan BY. Corporate governance in Asia. Asia Pacific Development Journal. 2004;11(2):1-32;Available from: https://doi.org/10.18356/c89f4feb-en.

44. Hu H, Tam O, Tan M. Internal governance mechanisms and firm performance in China. Asia Pacific Journal of Management. 2010;27(4):727-49;Available from: https://doi.org/10. 1007/s10490-009-9135-6.

45. Mohammad A-S, Abdussalam A-T. Ownership structure and firm performance: The case of Jordan. Journal of Business Administration. 2005;1(2);

46. Ponnu $\mathrm{CH}$. Corporate governance structures and the performance of Malaysian public listed companies. International Review of Business Research Papers. 2008;4(2):217-30;.

47. Tariq Y, Butt SA. Impact of corporate governance practices on financial performance: Empirical evidence from Pakistan. The 8th Annual Hawaii international conference on business (May 22-25, 2008); Honolulu, USA: SSRN; 2008;Available from: https: //doi.org/10.2139/ssrn.1648547.

48. Reddy K. The relationship between corporate governance practices and financial performance in New Zealand: An empirical investigation [Doctoral thesis]. Hamilton: The University of Waikato; 2010;Available from: https://doi.org/10.1108/ 17439131011056224.

49. Donaldson L, Davis JH. Stewardship theory or agency theory: CEO governance and shareholder returns. Australian Journal of Management. 1991;16(1):49-65;Available from: https://doi. org/10.1177/031289629101600103.

50. Fama EF, Jensen M. Separation of ownership and control. Journal of Law and Economics. 1983;26(2):301-25;Available from: https://doi.org/10.1086/467037.

51. Dalton DR, Daily CM, Johnson JL, Ellstrand AE. Number of directors and financial performance: A meta-analysis. Academy of Management journal. 1999:674-86;Available from: https: //doi.org/10.2307/256988.

52. Jensen M. Modern industrial revolution, exit, and the failure of internal control systems. Journal of Finance. 1993; 48:831-80;Available from: https://doi.org/10.1111/j.1540-6261. 1993.tb04022.x

53. Lipton M, Lorsch JW. A modest proposal for improved corporate governance. Business Lawyer. 1992;48(1):59-77;

54. Sonnenfeld JA. What makes great boards great. Harvard Business Review. 2002;80(9):106-13;.

55. Yermack D. Higher market valuation of companies with a small board of directors. Journal of Financial Economics. 1996;40(2):185-211;Available from: https://doi.org/10.1016/ 0304-405X(95)00844-5.

56. Garg AK. Influence of board size and independence on firm performance: A study of Indian companies. Vikalpa. 2007;32(3):39;Available from: https: //doi.org/10.1177/0256090920070304.

57. Mak YT, Kusnadi Y. Size really matters: Further evidence on the negative relationship between board size and firm value. Pacific-Basin Finance Journal. 2005;13(3):301-18;Available from: https://doi.org/10.1016/j.pacfin.2004.09.002.

58. Beiner S, Drobetz W, Schmid MM, Zimmermann H. An integrated framework of corporate governance and firm valuation. European Financial Management. 2006;12(2):24983;Available from: https://doi.org/10.1111/j.1354-7798.2006. 00318.x.

59. Maassen GF. An international comparison of corporate governance models. 3 ed. DZ Amsterdam, The Netherlands: Spencer Stuart; 2002;

60. Nguyen A, Nguyen T. Working capital management and corporate profitability: Empirical evidence from Vietnam. Foundations of Management. 2018;10(1):195-206;Available from: https://doi.org/10.2478/fman-2018-0015.

61. Nguyen A, Nguyen T. Free cash flow and corporate profitability in emerging economies: Empirical evidence from Vietnam. Economics Bulletin. 2018;38(1):211-20;Available from: https: //doi.org/10.2478/fman-2018-0015.

62. Bozec R. Boards of directors, market discipline and firm performance. Journal of Business Finance \& Accounting. 2005;32(9 \& 10):1921-60;Available from: https://doi.org/10.1111/j.0306686X.2005.00652.x.

63. Shleifer A, Vishny RW. Large shareholders and corporate control. Journal of Political Economy. 1986;94(3):461-88;Available from: https://doi.org/10.1086/261385.

64. La Porta R, Lopez-de-Silanes F, Shleifer A, Vishny R. Investor protection and corporate governance. Journal of Financia Economics. 2000;58(1\&2):3-27;Available from: https://doi.org/ 10.1016/S0304-405X(00)00065-9.

65. Ntim CG. Internal corporate governance structures and firm financial performance: Evidence from South African listed firms [Doctoral thesis]: University of Glasgow; 2009;

66. Morck R, Shleifer A, Vishny RW. Management ownership and market valuation: An empirical analysis. Journal of Financial Economics. 1988;20:293-315;Available from: https://doi.org/ 10.1016/0304-405X(88)90048-7. 


\section{Các lý thuyết chủ lưu về quản trị công ty và mối quan hệ giữa quản trị công ty và hiệu quả tài chính}

\section{Nguyễn Văn Tuấn*}

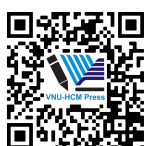

Use your smartphone to scan this QR code and download this article

Khoa Kinh tế và Quản tri kinh doanh, Trương Đại học Đà Lạt, Việt Nam

Liên hệ

Nguyễn Văn Tuấn, Khoa Kinh tế và Quản trị kinh doanh, Trường Đại học Đà Lạt, Việt Nam

Email: tuannv@dlu.edu.vn

Lịch sử

- Ngày nhận: 14-3-2021

- Ngày chấp nhận: 26-5-2021

- Ngày đăng: 09-6-2021

DOI : 10.32508/stdjelm.v5i3.781

\section{Check for updates}

\section{Bản quyền}

๑ ĐHQG Tp.HCM. Đây là bài báo công bố mở được phát hành theo các điều khoản của the Creative Commons Attribution 4.0 International license.

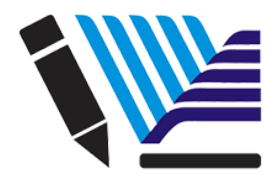

VNU-HCM Press

\section{TÓM TẮT}

Bài báo này xem xét các lý thuyết chủ đạo về quản trị công ty và mối quan hệ giữa các cấu trúc quản trị công ty và hiệu quả tài chính công ty. Chúng tôi chỉ ra rằng bốn lý thuyết chủ yếu thường được sử dụng để nghiên cứu mối quan hệ quản trị công ty - hiệu quả tài chính công ty là lý thuyết đại diện, lý thuyết nhà quản lý, lý thuyết phụ thuộc nguôn lực, và lý thuyết thể chế. Mặc dù là một cách tiếp cận chiếm ưu thế áp đảo trong các nghiên cứu về quản trị công ty, lý thuyết đại diện trong thời gian gần đây bị nhiều chỉ trích vì không phản ánh một cách đầy đủ các thực tiễn quản trị công ty trong các bối cảnh thể chế khác nhau. Do đó, cần phải kiểm tra lại khuôn khổ phân tích ủy quyền - tác nghiệp truyền thống để có thể hiểu rõ hơn mối quan hệ quản trị công ty - hiệu quả tài chính công ty trong các môi trường thể chế khác nhau. Cũng có những lời kêu gọi nên áp dụng phương pháp tiếp cận đa lý thuyết nhằm nắm bắt bản chất phức tạp của mối quan hệ quản trị công ty - hiệu quả tài chính công ty. Nghiên cứu này của chúng tôi chỉ ra rằng tác động của quản trị công ty đối với hiệu quả tài chính công ty là không rõ ràng vì các phát hiện thực nghiệm liên quan đến mối quan hệ này là không nhất quán trong các bối cảnh phân tích khác nhau. Có ý kiến cho rằng những phát hiện thiếu nhất quán như vậy về mối quan hệ giữa quản trị công ty và hiệu quả tài chính công ty có thể là do sự khác biệt vể thể chế quốc gia và sự không hoàn hảo của các kỹ thuật ước lượng. Một số nghiên cứu gần đây về quản trị công ty ủng hộ quan điểm cho rằng việc thực thi các cơ chế quản trị công ty ở một quốc gia chịu ảnh hưởng bởi môi trường thể chế của quốc gia đó. Vi vậy, hiệu lực của các cơ chế quản trị công ty sẽ khác nhau giữa các quốc gia, hay nói cách khác, mang tính đặc thù của từng quốc gia. Điều này gợi ý rằng các nghiên cứu trong tương lai lấy bối cảnh so sánh giữa các quốc gia sẽ có thể cung cấp thông tin chi tiết và chuyên sâu hơn về mối quan hệ giữa quản trị công ty và hiệu quả tài chính công ty. Chúng tôi đề xuất rằng các nghiên cứu so sánh về quản trị công ty xuyên quốc gia cũng cần tính đến tác động trung gian tiềm năng của các đặc điểm thể chế của quốc gia mà trong đó các công ty đang hoạt động.

Từ khoá: Lý thuyết đại diện, Quản trị công ty, Lý thuyết thể chế, Lý thuyết phụ thuộc nguồn lực, Lý thuyết nhà quản lý 